\title{
The Relationship Between Structural Root Depth and Vigor of Urban Trees
}

\author{
Gary W. Watson and Angela M. Hewitt
}

\begin{abstract}
The prevalence of deep root systems on urban trees has been well documented, but the consequences are not well understood. The relationship between structural root depth and vigor of street trees was investigated in Greensboro, North Carolina; Snoqualmie, Washington; and Glen Ellyn, Illinois, United States. Regression analysis was used to explore the relationship between root depth and crown vigor, trunk diameter growth, and trunk condition as indicators of tree performance. The average depth of structural roots for most species was less than three centimeters. However, in 10 of the 14 species included in the study, the structural roots of $20 \%-60 \%$ of the individual trees were more than eight centimeters deep. Regression analysis showed a significant relationship between root depth and indicators of tree performance for Acer rubrum, Quercus bicolor, Fraxinus oxycarpa, and Tilia cordata, but no relationship was identified for other species measured. Root depth explained less than half of the reduction in tree performance of these species, however, and is apparently only one of several factors affecting the growth of street trees.

Key Words. Buried Roots; Deep Planting; Root Architecture.
\end{abstract}

Excessively deep root systems are common on trees in urban and suburban landscapes. The structural woody roots that collectively form the root flare have been found to be more than $7.6 \mathrm{~cm}$ below the soil surface on up to two-thirds of street trees in several Illinois and Minnesota, U.S., cities (Watson et al. 1990; Giblin et al. 2006). In Long Island, New York, U.S., the average depth of soil over the structural roots was slightly more than $15 \mathrm{~cm}$ (Smiley 2006). This is deeper than the best management practice (BMP) recommendation that "at least two structural roots should be within 2.5 to $7.6 \mathrm{~cm}$ of the soil surface" (Watson and Himelick 2005).

In addition to simply planting trees too deeply in the landscape, nursery field production practices can also contribute to deep root systems (Harris et al. 2001; Hewitt and Watson $2009)$. In the 1980s, deep roots were reported on New York City, New York, U.S., trees and were attributed to nursery practices prior to planting (Berrang et al. 1985). In a study of Ohio, U.S. nurseries, the average depth of structural roots in nursery fields and harvested root balls has been reported at 2-10 cm and 7-11 cm, respectively (Rathjens et al. 2007).

The question of how the deep root systems are affecting tree performance has not been adequately answered. Controlled experiments in field plots showed that deep root systems reduce survival and growth under some conditions, especially poor drainage (Wells et al. 2005; Arnold et al. 2005; Arnold et al. 2007; Bryan et al. 2010; Day and Harris 2008). Similar studies are lacking on trees planted in urban and suburban landscapes where many factors can affect tree growth and vigor. This study attempts to understand whether root depth affects vigor of commonly planted street trees in Greensboro, North Carolina (NC); Snoqualmie, Washington (WA); and Glen Ellyn, Illinois (IL).

\section{METHODS}

Arborists were contacted to locate suitable street tree plantings for the study. Knowledge of site history and consistency in site conditions were important considerations. Tree inventory records were examined from nine locations, six were visited for evaluation, and three were chosen.

\section{Study Sites}

Sites were chosen based on their geographic and climatic differences, species and number of trees available, and availability of local cooperators. The NC site was a large commercial property where the space between the pedestrian sidewalk and street curb was less than two meters wide and too narrow for planting. Therefore trees were planted one meter from the sidewalk on the side away from the street with $10 \mathrm{~m}$ or more open space beyond. A single cultivar of (Acer rubrum) trees was growing along the entire street.

The WA site was a residential neighborhood. Planting space width between the pedestrian sidewalk and street curb was somewhat variable from street to street but was typically less than two meters. A single species or cultivar was planted along each street. Streets with Quercus rubra, Fraxinus oxycarpa, and Tilia cordata were used in the study.

The IL site also consisted of street trees in a residential neighborhood. Planting space was also of variable width. Plantings along each street were of mixed species. When there were insufficient numbers of trees of a species for valid data analysis, the data were reported by genus. All trees were considered well-established. Trees in NC and WA were all planted as a group at the same time, 5 to 10 years earlier, but the exact year of planting was not available from records. 
Table 1. Root depth and indicators of tree performance were recorded on street trees from three locations. A visual rating system was used for crown vigor. Where insufficient trees were available for some species, data is reported by genus. A trunk condition rating system was also used as a measure of performance at the North Carolina site because of a history of Phytophthora basal lesions.

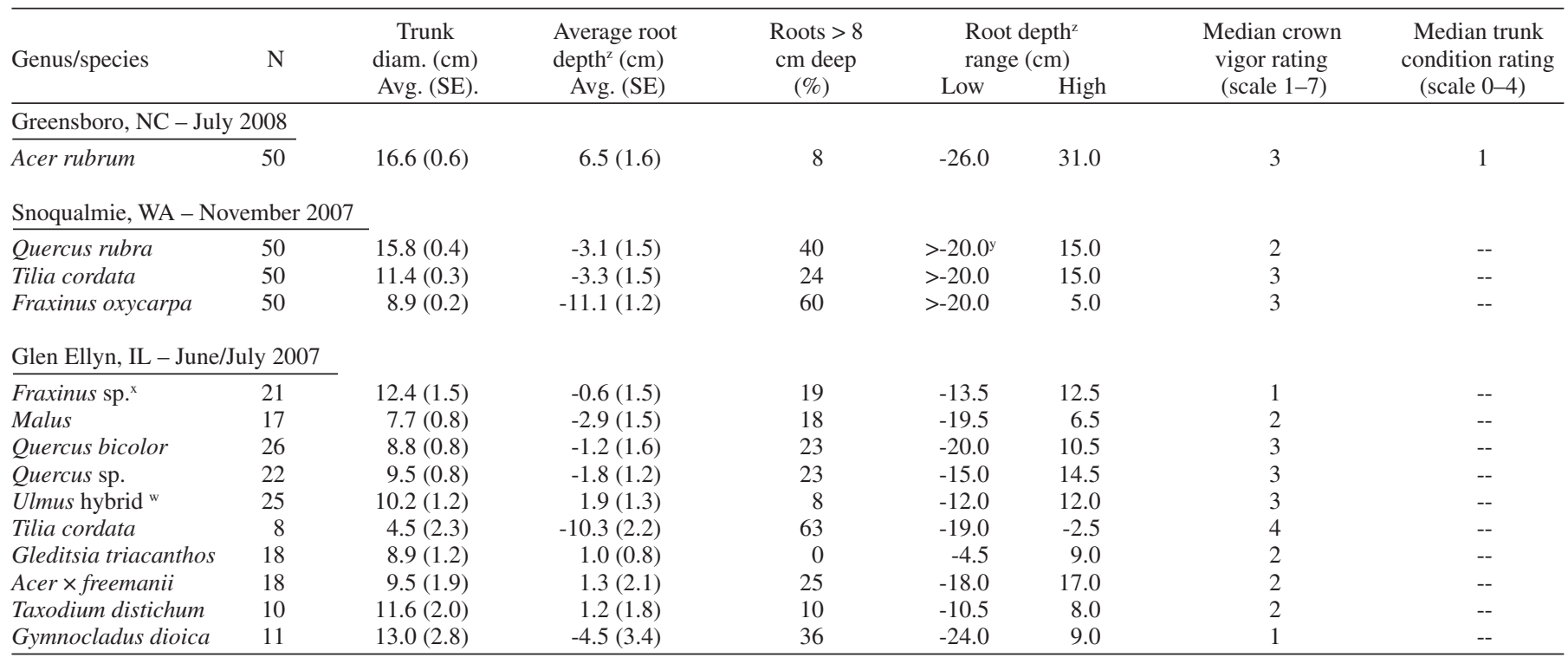

${ }^{\mathrm{z}}$ Positive numbers indicate roots are above surrounding grade.

${ }^{y}$ Hand excavation only on this site, $20 \mathrm{~cm}$ was maximum possible.

${ }^{\mathrm{x}} F$. pennsylvanica and $F$. americana cultivars are usually grafted on $F$. pennsylvanica root stock.

w Hybrid elm cultivars are usually grafted on Ulmus pumila root stock.

All trees were planted as ball-and-burlap stock, and trees were surrounded by turfgrass beyond a small $(1-1.5 \mathrm{~m})$ mulch ring at the base of the tree. Sampling dates and species for each site are listed in Table 1.

\section{Root Depth}

The root flare is the commonly used reference point for root depth discussions, but is really a zone rather than a specific point that can be measured precisely. To be more specific in this study, and in compliance with best management practices (Watson and Himelick 2005), root depth was measured from the upper surface of individual roots at the point where the root became distinct from the trunk. Depth was measured to the nearest half-centimeter relative to the soil against the trunk. The depth of individual roots usually varied around the tree. The depth of the two uppermost woody structural roots was recorded for each tree and averaged. If the soil against the trunk was higher or lower than the surrounding grade, this measurement was recorded and root depth relative to surrounding grade was calculated.

Root collars were excavated with hand tools and pneumatic excavation, depending on circumstances at each site. At WA, hand digging was the only option, and root collars were excavated to a maximum depth of $20 \mathrm{~cm}$. Further hand excavation would have caused more site disruption than was tolerable. If no roots were found within $20 \mathrm{~cm}$, depth was recorded as $>20 \mathrm{~cm}$. At IL, root collars were first excavated by hand to a depth of 15 $\mathrm{cm}$, and if roots were not exposed, a pneumatic excavation tool was used on a return visit to excavate until roots were located.

At the NC site, root collars had been excavated several months earlier to expose the structural roots because Phytophthora lesions were discovered on the lower portion of the trunk (pers. comm.: E.
Thomas Smiley). The depressions were filled with coarse mulch that was easily removed by hand to re-expose the structural roots.

\section{Tree Performance}

A visual rating system was developed for crown vigor. Trees were rated during the dormant season at WA, and only twig growth could be rated.

Vigor ratings:

1 - Vigorous: Terminal twig growth; leaf size and color better than average for species.

2 - Normal: Terminal twig growth; leaf size and color typical of species.

3 - Acceptable: Terminal twig growth; leaf size and color less than typical, but acceptable.

4 - Stress overcome: History of subnormal twig growth or minor twig dieback, but now acceptable or better.

5 - Current stress: Subnormal twig growth; leaves small, scorched or off color; minor dieback.

6 - Significant dieback: Major portions of crown dead, still in decline.

7 - Replacement needed: Dead or nearly so.

In addition to crown evaluations, trunk condition was also rated at the North Carolina site. This tree-health variable was included because these trees had a history of Phytophthora lesions on the lower portion of the trunk. The scale was based on visual estimation of the portion of the trunk circumference damaged by the disease lesion: $0=0 \%, 1=$ $1 \%-25 \%, 2=26 \%-50 \%, 3=51 \%-75 \%, 4=76 \%-100 \%$.

Trunk diameter was measured with a diameter tape $15 \mathrm{~cm}$ above soil line prior to excavation. Trunk diameter was used to assess per- 
formance only on sites where trees of uniform size, from the same source, were all planted at the same time (NC, WA).

\section{Statistical Procedures}

Regression analysis was used to examine the relationship between root depth and tree performance, with depth as the independent variable, and crown vigor, trunk condition, or trunk diameter as the dependent variable. Linear regression was used for trunk diameter measurement data (SAS procedure PROC REG, SAS 9.2). Significance is reported for $P<0.05$. Crown vigor and trunk condition ratings were analyzed with logistic regression (SAS procedure PROC LOGISTIC, SAS 9.2) with Somers'D used as an indicator of model fit. Significance is reported at $\chi^{2}$ probability $P<0.05$.

\section{RESULTS AND DISCUSSION}

Root depth showed high variability on all sites. Only Fraxinus oxycarpa and Tilia cordata structural root depth averaged greater than $7.5 \mathrm{~cm}$, the maximum depth recommended by best management practices (Watson and Himelick 2005). The average depth of the structural roots was less than $3 \mathrm{~cm}$ for most species. The range of root depths may reflect the situation more meaningfully. The range of uppermost structural root depth of individual trees was in excess of $20 \mathrm{~cm}$ for most species. Within that broad range, the shallowest roots of $20 \%-60 \%$ of the individual trees were more than $7.5 \mathrm{~cm}$ deep in 10 of the 14 species included in the study (Table 1). This agrees with previous studies where similar numbers of trees with roots more than $7.6 \mathrm{~cm}$ deep were reported (Watson et al. 1990; Giblin 2006).

Regression analysis showed a significant relationship between root depth and tree performance for some species. Increasing root depth did accompany at least one measure of tree performance in four species (Table 2; Figure 1). Crown vigor and trunk condition of Acer rubrum decreased with increasing root depth at NC. Crown vigor was reduced in Quercus bicolor for IL, but not for any of the other species evaluated at the same site. Trunk diameter growth of Fraxinus oxycarpa and Tilia cordata was reduced at WA, but there was no relationship evident for $Q$. rubra. It was not within the scope of this study to determine what specific soil conditions may have been responsible for reducing the growth and vigor of trees with deep root systems.

Species generally considered highly tolerant of urban landscape conditions (Gilman 1997; Dirr 2009) showed no significant relationship between root depth and condition. These include Fraxinus sp. (F. pennsylvanica and F. Americana cultivars are both commonly grafted on $F$. pennsylvanica root stock), Acer $\times$ freemani, Malus sp., Gymnocladus dioica, Taxodium distichum, Ulmus hybrid (often grafted onto Ulmus pumila root stock). These species are planted frequently in urban areas because they can tolerate a wide variety of conditions, including deposition of soil over the roots in flooding events in nature. These species proved to be the most capable of tolerating deep root systems. Q. rubra and Quercus sp. (primarily $Q$. macrocarpa and $Q$. muehlenbergii), generally considered moderately tolerant of urban site conditions, were also unaffected by root depth. Maximum root depth of Gleditsia triacanthos was 4.5 $\mathrm{cm}$, which is within the BMP guidelines for root depth (Watson and Himelick 2005) and understandably this species showed no relationship between root depth and tree performance.

Crown vigor was not related to root depth for any species on the WA site. The coastal regions in the Pacific Northwest are known for their nearly ideal growing conditions. The WA site was at an elevation of $243 \mathrm{~m}$ in the Cascade Mountains. Average high temperature during the summer months is $7^{\circ} \mathrm{C}$ cooler than the other two sites $\left(22^{\circ} \mathrm{C}\right.$ versus $\left.29^{\circ} \mathrm{C}\right)$ (www.intellicast.com). Symptoms of stress or dieback may be less likely to develop when above ground conditions are less stressful, even if root system function is reduced by a

Table 2. Regression analysis was used to determine the relationship between root depth and tree performance, with depth as the independent variable and crown vigor or trunk diameter (only on sites where trees of uniform size from the same source were all planted at the same time) as the dependent variable. Logistic regression was used for crown vigor and trunk condition ratings. Linear regression was used for trunk diameter measurements. Where insufficient trees were available for some species, data is reported by genus.

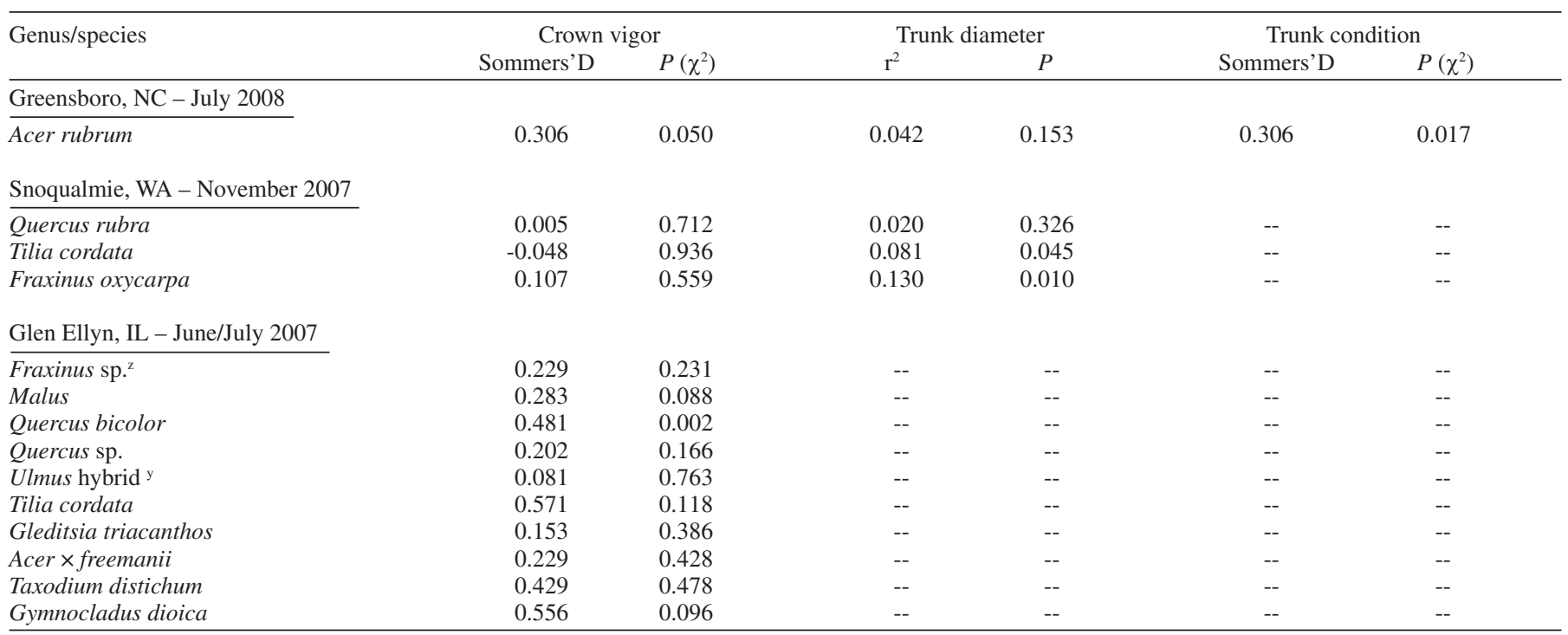

${ }^{\mathrm{z}} F$. pennsylvanica and $F$. americana cultivars are usually grafted on $F$. pennsylvanica root stock.

${ }^{y}$ Hybrid elm cultivars are usually grafted on Ulmus pumila root stock. 


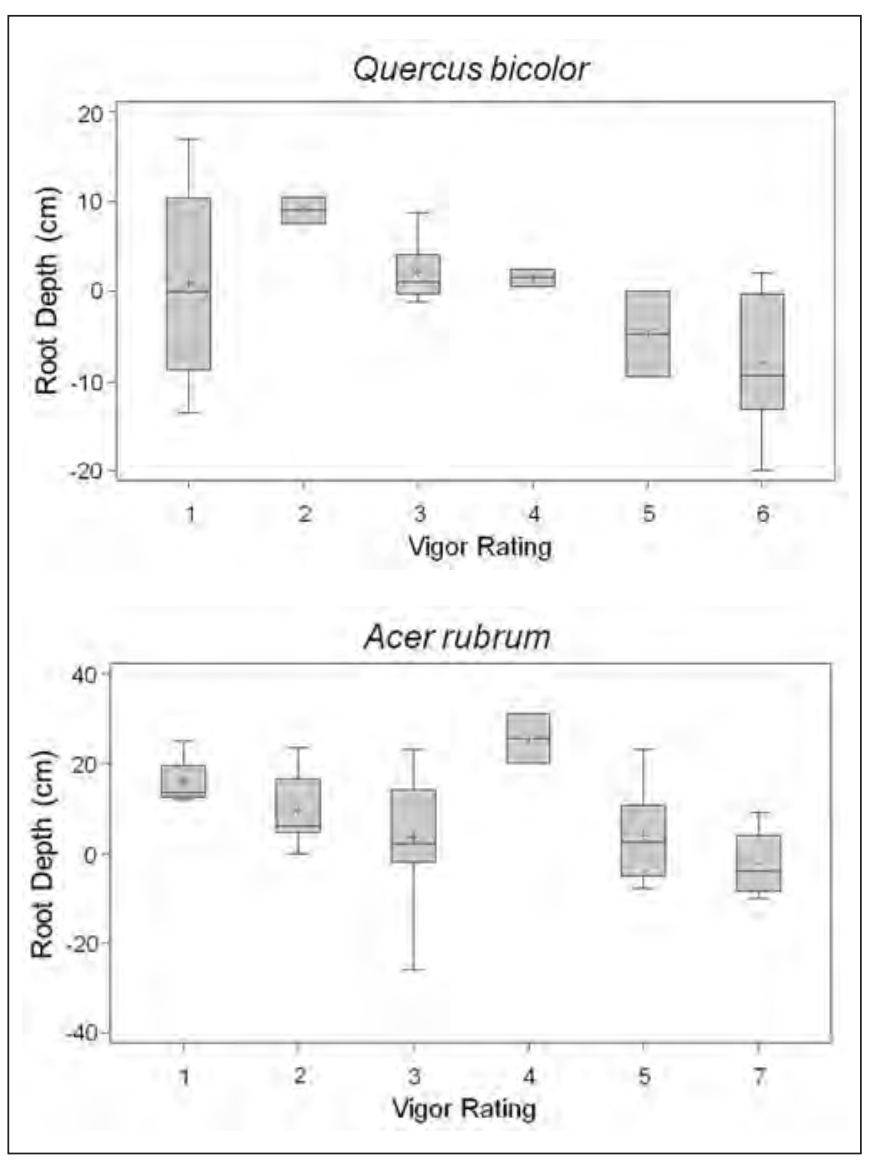

Figure 1. Box plots for species exhibiting a significant relationship between root depth and crown vigor rating ( $1=$ vigorous, $7=$ replacement needed).

deep root system. Trunk diameter growth was reduced on two of the three species (Table 2), possibly reflecting overall lower performance, though crown appearance was acceptable.

At most, root depth could explain less than half of the reduction in crown vigor, trunk condition, or trunk diameter growth. Root depth is only one of several factors affecting tree performance on street tree plantings. Soil conditions, seedling rootstocks, and installation and maintenance procedures on street tree planting sites can be highly variable, even within an apparently uniform planting on the same street. High variability in non-experimental field plots compared to their more controlled counterparts can make potential effects of deep root systems on tree vigor difficult to discern.

\section{CONCLUSIONS}

These results show that deep root systems are not causing widespread decline and losses to urban trees in the first ten years after planting. There was a significant relationship between root depth and tree performance for only some species, explaining less than half of the reduction in any indicator of performance. Most of the species included in this study were considered at least moderately tolerant of adverse conditions. Deep roots may have a greater effect on more sensitive species. Even a modest reduction in vigor could be serious for species that find it challenging to grow in urban landscapes, and for many moderately sensitive species on very difficult sites.
The range of data collected in this initial study was limited. Information on a wider variety of species is needed. Given the accepted variability of soils on urban sites, more information on site soil conditions could improve researchers' understanding of which factors are most affecting tree performance.

Though the reduction of tree performance due to deep roots was modest, the problem may be so widespread that there could still be a significant impact on the urban forest as a whole. When all species are combined, the structural roots were at least $8 \mathrm{~cm}$ deep on $26 \%$ of the trees. Growth and vigor is being reduced in some cases by as much as $50 \%$. The potential reduction in ecosystem services provided by these underperforming trees over their lifetime could be substantial.

Acknowledgments. This study was funded in part by a grant from the USDA Forest Service Urban and Community Forestry Program on the recommendation of the National Urban and Community Forestry Advisory Council. Cooperators providing invaluable assistance at the study sites were E. Thomas Smiley, Liza Holmes, and Elizabeth Schulte of Bartlett Tree Research Laboratories; Jim Barbarinas, Urban Forestry Services, Inc; Linda Chalker-Scott and Eric Eulenberg, WSU Puyallup Research and Extension Center; Peggy Drescher, Charles Shonte, and Glenn Willis, Village of Glen Ellyn; and Kristen Vollrath, The Morton Arboretum.

\section{LITERATURE CITED}

Arnold, M.A., G.V. McDonald, and D.L. Bryan. 2005. Planting depth and mulch thickness affect establishment of green ash (Fraxinus pennsylvanica) and bougainvillea goldenrain tree (Koelreuteria bipinnata). Journal of Arboriculture 31:163-170.

Arnold, M.A., G.V. McDonald, D.L. Bryan, G.C. Denny, W.T. Watson, and L. Lombardini. 2007. Below-grade planting adversely affects survival and growth of tree species from five different families. Arboriculture \& Urban Forestry 33:64-69.

Berrang, P., D.F. Karnosky, and B.J. Stanton. 1985. Environmental factors affecting tree health in New York City. Journal of Arboriculture 11:185-189.

Bryan, D.L., M.A. Arnold, A. Volder, W.T. Watson, L. Lombardini, J.J. Sloan, L.A. Valdez-Aguilar, and A.D. Cartmill. 2010. Transplant season, irrigation, and planting depth effects on landscape establishment of bald cypress and sycamore. Arboriculture \& Urban Forestry 36:57-65.

Day, S.D., and J.R. Harris. 2008. Growth, survival, and root system morphology of deeply planted Corylus colurna seven years after transplanting and the effects of root collar excavation. Urban Forestry \& Urban Greening 7:119-128.

Dirr, M.A. 2009. Manual of Woody Landscape Plants (Sixh Edition). Stipes Publishing L.L.C., Champaign, Illinois, U.S. 1325 pp.

Giblin, C, J. Gillman, D. Hanson, G.R. Johnson, and P. Weicherding. 2006. The effects of soil depth on the long-term health and frequency of storm damage to trees in the upper Midwest, pp. 33-39. In: G. Watson (Ed.). Proceedings of Trees and Planting: Getting the Roots Right Conference. <www.mortonarb.org/deeptreeroots/pdf/GRR_Proceedings.pdf\#TOC>

Gilman, E.F. 1997. Trees for Urban and Suburban Landscapes. Delmar Publishers, Albany, New York, U.S. 662 pp.

Harris, J.R., J. Fanelli, A. Niemiera, and R. Wright. 2001. Root pruning pin oak liners affects growth and root morphology. HortTechnology 11:49-52. 
Hewitt, A., and G. Watson. 2009. Bare root liner production can alter tree root architecture. Journal of Environmental Horticulture 27:99-104.

Rathjens, R.G., T.D. Sydnor, and D.S. Gardner. 2007. A survey of the depth of the main lateral roots of nursery trees in Ohio before and after harvest. Journal of Environmental Horticulture 25:187-190.

Smiley, E.T. 2006. Root collar excavations to improve tree health, pp. 49-50. In: G. Watson (Ed.). Proceedings of Trees and Planting: Getting the Roots Right Conference. <www.mortonarb.org/deeptreeroots/pdf/GRR_Proceedings.pdf\#TOC>

Watson, G.W., S. Clark, and K. Johnson. 1990. Formation of girdling roots. Journal of Arboriculture 16:197-202.

Watson, G., and E.B. Himelick. 2005. Best Management Practices: Tree Planting. International Society of Arboriculture, Champaign, Illinois, U.S. 41 pp.

Wells, C.E., K.S. Townsend, J.D. Caldwell, D.L. Ham, E.T. Smiley, and M. Sherwood. 2005. Effects of planting depth on landscape tree survival and girdling root formation. Arboriculture \& Urban Forestry 32:305-311.

Gary Watson (corresponding author)

Head of Research

The Morton Arboretum

Lisle, IL 60532, U.S.

gwatson@mortonarb.org

Angela Hewitt

Research Specialist

The Morton Arboretum

Lisle, IL 60532, U.S.
Résumé. La prévalence des systèmes racinaires profonds chez les arbres urbains a été bien documentée, mais les conséquences ne sont pas bien comprises. La relation entre la profondeur des racines structurales et la vigueur des arbres de rues a été étudiée à Greensboro (Caroline du Nord), à Snoqualmie (Washington) et à Glen Ellyn (Illinois) aux ÉtatsUnis. Une analyse de régression a été employée afin d'explorer la relation entre la profondeur des racines et la vigueur de la couronne, la croissance en diamètre du tronc ainsi que la condition du tronc en tant qu'indicateurs de la performance de l'arbre. La profondeur moyenne en racines structurales était inférieure à $3 \mathrm{~cm}$ pour la plupart des espèces. Cependant, chez 10 des 14 espèces comprises dans cette étude, les racines structurales de $20 \%$ à $60 \%$ des individus étaient à plus de $8 \mathrm{~cm}$ de profondeur. L'analyse de régression a montré une relation significative entre la profondeur des racines et les indicateurs de performance de l'arbre chez Acer rubrum, Quercus bicolor, Fraxinus oxycarpa et Tilia cordata, mais aucune relation n'a été identifiée chez les autres espèces étudiées. La profondeur des racines explique moins de la moitié de la diminution en performance chez les autres espèces, mais elle constitue néanmoins l'un des facteurs affectant la croissance des arbres de rues.

Zusammenfassung. Die Verbreitung von tiefen Wurzelsystemen be Straßenbäumen ist gut dokumentiert, aber die Konsequenzen sind nicht ganz verstanden. Die Beziehung zwischen struktureller Wurzeltiefe und Wüchsigkeit von Straßenbäumen wurde in Greensboro, North Carolina; Snoqualmie, Washington; und Glen Ellyn, Illinois, Vereinigte Staaten, untersucht. Eine Regressionsanalyse wurde verwendet, um die Beziehung zwischen Wurzeltiefe und Kronenwüchsigkeit, Stammdurchmesserwachstum und Stammkonditionen als Indikatoren für den Gesamtauftritt des Baumes zu erforschen. Die durchschnittliche Tiefe struktureller Wurzeln liegt bei den meisten Arten unter $3 \mathrm{~cm}$. Dennoch zeigte sich bei 10 - 14 an dieser Studie beteiligten Arten, dass die strukturellen Wurzeln von 20\% - 60\% der einzelnen Bäume mehr als $8 \mathrm{~cm}$ tief lagen. Die Regressionsanalyse zeigte eine signifikante Relation zwischen der Wurzeltiefe und den Indikatoren der Gesamtdarstellung für Acer rubrum, Quercus bicolor, Fraxinus oxycarpa und Tilia cordata, aber bei den anderen gemessenen Arten wurde keine Relation identifiziert. D dennoch erklärt die Wurzeltiefe weniger als die Hälfte der Reduktion in der Gesamterscheinung der beteiligten Arten, und ist offensichtlich nur einer von vielen Faktoren, die das Wachstum von Straßenbäumen erklären.

Resumen. La prevalencia de sistemas de raíces profundas en los árboles urbanos ha sido bien documentada, pero las consecuencias no han están bien entendidas. Se investigó la relación entre la profundidad de las raíces estructurales y el vigor de árboles de las calles en Greensboro, North Carolina; Snoqualmie, Washington; y Glen Ellyn, Illinois, Estados Unidos. Se utilizó análisis de regresión para explorar la relación entre profundidad de la raíz y vigor de la copa, crecimiento del diámetro del tronco y condición del tronco, como indicadores del comportamiento del árbol. La profundidad media de las raíces estructurales para la mayoría de las especies fue menor de tres $\mathrm{cm}$. Sin embargo, en 10 de las 14 especies incluidas en el estudio, las raíces estructurales de 20\%-60\% de los árboles fueron de más de ocho $\mathrm{cm}$ de profundidad. El análisis de regresión mostró una relación significante entre la profundidad de raíces e indicadores de comportamiento del árbol para Acer rubrum, Quercus bicolor, Fraxinus oxycarpa, y Tilia cordata, pero no se identificó relación para otras especies medidas. La profundidad de la raíz explicó menos de la mitad de la reducción en el comportamiento del árbol de estas especies; sin embargo, es aparentemente solo una de los varios factores que afectan el crecimiento de los árboles urbanos. 